\title{
Effect of Planting Date and Plant Spacing on the Rotenoid Production of Tephrosia vogelii in Puerto Rico'
}

\author{
R. H. Freyre and D. K. Barnes ${ }^{2}$
}

INTRODUCTION

The commercial sources of rotenone at present are the roots of certain species of Derris and Lonchocarpus. These are tropical plants grown in areas outside the continental United States. The U. S. Department of Agriculture has been interested for several years in the possibility of developing a source of rotenone which could be grown economically in the continental United States and Puerto Rico.

Various plant parts of 16 Tephrosia species were evaluated for rotenoid content $(5){ }^{3}$ The highest rotenoid content was found in leaves of $T$. vogelii Hook. f. Subsequent studies $(3,6)$ demonstrated significant differences in rotenoid content among plant introductions and breeding lines. Nevertheless, it is necessary to increase the rotenoid content of $T$. vogelii leaves before commercial production is feasible. Although Tephrosia grows vigorously in the southeastern United States, the climatic conditions required for flowering and seed production make it necessary to conduct all breeding programs in Puerto Rico.

Barnes et al. (3) in a previous study demonstrated that varietal comparisons based on percentage rotenoid content were not influenced by latitude; i.e., plants selected for high rotenoid content in Puerto Rico also produced high rotenoid content in the continental United States. Plant rotenoid content was unaffected by planting distance. However, plant growth characteristics such as plant height, leaf-to-stem ratio, and total yield of stems and leaves per hectare, were influenced by within-row spacing and latitude. Because of these significant interactions, the same authors concluded that additional crop management studies were needed at each latitude before the most profitable crop production practices could be determined.

This paper reports results of an experiment designed to study the effect of plant spacing and time of planting on the production of $T$. vogelii grown in Puerto Rico. The plant characteristics studied included rotenoid content

' Contribution from Crops Research Division, Agricultural Research Service, USDA, Federal Experiment. Station, Mayagüez, P.R. 00708.

${ }^{2}$ Research Agronomist, Mayagüez, P.R., and Research Geneticist, Department of Agronomy and Plant Genetics, Univ. of Minnesota, St. Paul, Minnesota (formerly, Mayagüez, P.R.).

${ }^{3}$ Italic numbers in parentheses refer to Literature Cited, p. 93. 
of the leaves, leaf-to-stem ratio, plant height, total yield of leaves and stems and seed production.

\section{MATERIALS AND METHODS}

Four varieties were used in these studies. They were three plant introductions (P.I. 257533, P.I. 248228, and P.I. 215495) and a high rotenoid breeding line developed in Puerto Rico at the Federal Experiment Station (6286). Seed for all plantings was scarified, treated with Thiram, and planted 1 to 2 $\mathrm{cm}$. deep, according to the recommendations made by Ruppel et al. (7). Plantings were made on a Toa silty clay loam at Mayagüez, P. R., on April 1, April 29, and May 27, 1964. We incorporated $275 \mathrm{~kg}$. of 10-10-8 commercial fertilizer and 14.03 liters of Aldrin per hectare into the top 15 cm. of soil with a rotary cultivator the day before planting. A side dressing of $90 \mathrm{~kg}$. of 5-10-10 fertilizer was applied to the first two plantings on July 28 and to the third planting on August 17.

We used a split-split plot design in which planting dates were the main plots, plant spacings were the subplots, and varieties the sub-subplots. Each sub-subplot consisted of one 7-meter row replicated three times in each planting date at each planting distance. Rows were spaced 1 meter apart. Plots were direct-seeded and 4 to 5 weeks later thinned to within-row spacing distances of about $19 \mathrm{~cm} ., 34 \mathrm{~cm}$. and $57 \mathrm{~cm}$. These correspond to population densities of $52,500,29,500$, and 17,500 plants per hectare.

Rotenoid samples were taken from each variety when approximately 10 percent of the plants in that particular variety were in flower. Varieties differed in their blooming periods. Sampling for the first planting therefore extended from September 8 to October '26; sampling for the second planting varied from September 28 to November 2; and sampling for the third planting varied from October 26 to November 23. Sampling and assay procedures for leaf rotenoids were those described by Barnes and Freyre (1). Plant height measurements were taken at the time leaf samples were collected for rotenoid analyses. After the completion of rotenoid sampling, we cut off half the plants in each plot at ground level. Leaves and stems were separated and weighed. The remaining plants were left standing for seed production. Data were analyzed by analyses of variance and the means ranked according to the Duncan's Multiple Range Test (4).

\section{EXPLRIMENTAL RESULTS}

Planting date influenced the number of days from planting to flower for two of the four varieties (table 1). The differential response of 6286 and P'.I. 257533 is assumed to result from photoperiodic sensitivity. P.I. 21549; and J.I. 248228 appeared generally to be insensitive to the photoperiods prevailing during the study. Within-row spacing generally had no effect on 
flowering within planting dates, except possibly for P.I. 248228 and P.I. 215495 in the April 29 planting.

Plant height at harvest was significantly affected by both within-row spacing and varieties (table 2). The closer plant spacings increased plant height. The mean plant height over all planting dates and varieties was 187,166 and $149 \mathrm{~cm}$. for the 19-, 34-, and 57-cm. within-row spacings, respectively.

TABLE 1.-Number of days from planting to first flower for four varieties of TEPHROsL vOGELII when planted at three spacing distances on three dates at Mayagriez, Puerto Rico

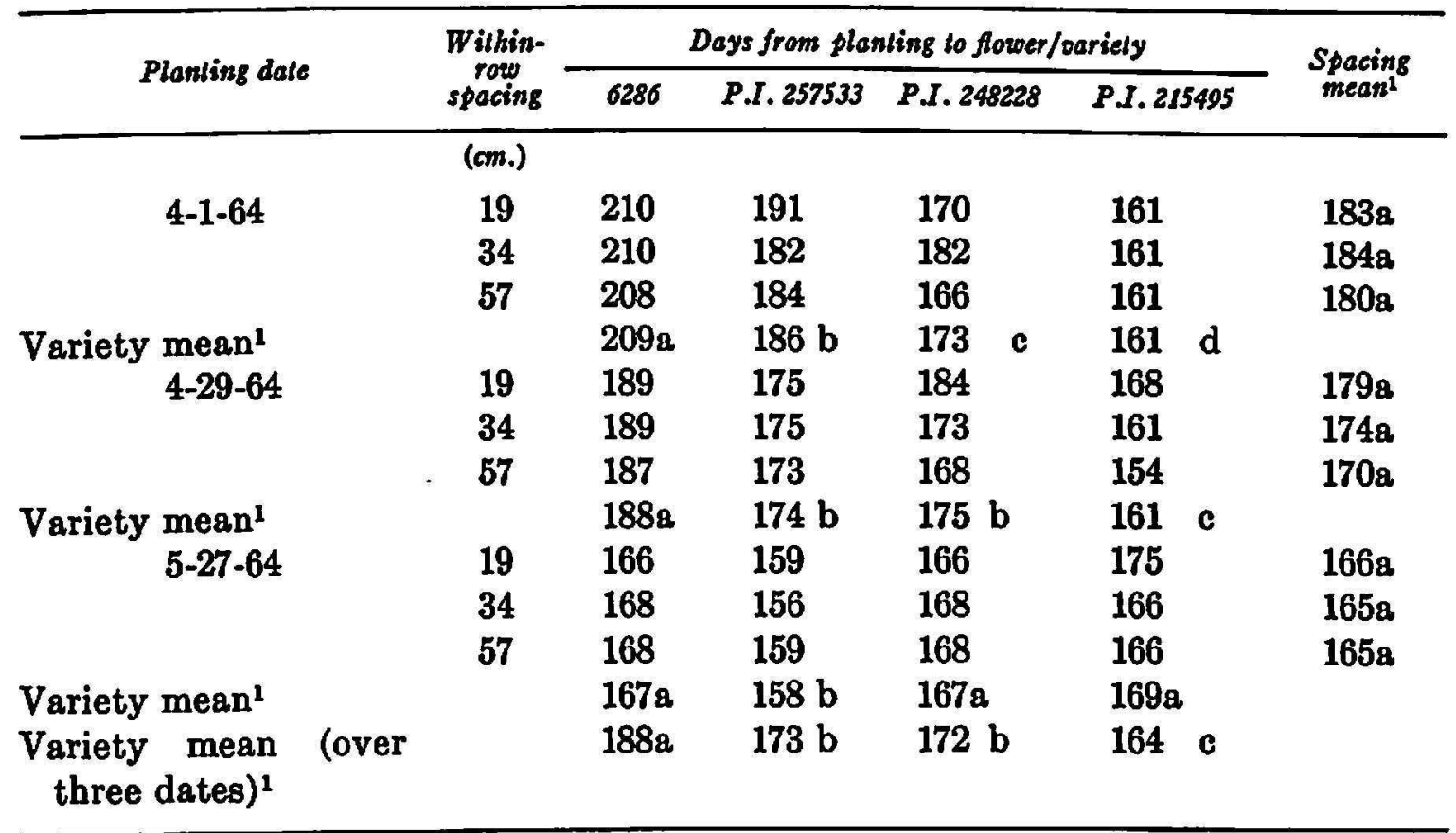

1 Variety means within each planting date, spacing mean within each planting date, and variety means over three planting dates, which have the same letter, do not differ at5-percentlevel of probability according to Duncan's Multiple Range Test.

Percent total rotenoids per unit of dry leaf weight was not influenced by planting date or within-row spacing (table 3). Significant differences were observed among varieties.

Total dry weight (leaves and stems) per hectare was not significantly affected by either planting date or variety, but was affected by within-row spacing (table 4). The mean dry weight yield over all planting dates and varieties was 14.2, 10.0, and 7.0 metric tons per hectare for the 19-, 34-, and 57-cm. within-row spacings, respectively. However, the proportion of leaves to stems was affected by planting date, within-row spacing and variety (table 5). The April 1 planting had a significantly lower percentage of leaves due to loss of leaves from diseases and senescence. The leaf-to-stem ratio was generally lower in the closely spaced plants. The mean leaf-to- 
TABLE 2.-Plant height at harvest of four varielies of TEPBROSLA VOGELI when grown at three spacing distances and planled on three dates at Mayagrtez,

Puerto Rico

\begin{tabular}{|c|c|c|c|c|c|c|}
\hline \multirow{2}{*}{ Planting dase } & \multirow{2}{*}{$\begin{array}{l}\text { Wilhing } \\
\text { roto } \\
\text { spacing }\end{array}$} & \multicolumn{4}{|c|}{ Plant height (contimeters/sariely) } & \multirow{2}{*}{ Spacing meant } \\
\hline & & 6286 & P.I. 257533 & P.I. 248228 & P.I. 215495 & \\
\hline & $C m$. & & & & & \\
\hline \multirow[t]{3}{*}{$4-1-64$} & 19 & 206 & 185 & 188 & 208 & $197 a$ \\
\hline & 34 & 201 & 160 & 185 & 163 & $177 \mathrm{ab}$ \\
\hline & 57 & 170 & 155 & 145 & 155 & $156 \mathrm{~b}$ \\
\hline Variety mean ${ }^{1}$ & & $192 \mathrm{a}$ & $167 \mathrm{a}$ & $173 a$ & $175 a$ & \\
\hline \multirow[t]{3}{*}{$4-29-64$} & 19 & 196 & 168 & 191 & 180 & $184 \mathrm{a}$ \\
\hline & 34 & 163 & 140 & 142 & 150 & $149 \mathrm{~b}$ \\
\hline & 57 & 155 & 117 & 124 & 135 & $133 \mathrm{~b}$ \\
\hline Variety mean ${ }^{1}$ & & $171 \mathrm{a}$ & 142 & 152 bc & $155 \mathrm{~b}$ & \\
\hline \multirow[t]{3}{*}{$5-27-64$} & 19 & 175 & 165 & 175 & 203 & $180 \mathrm{~s}$ \\
\hline & 34 & 173 & 155 & 188 & 175 & $173 a$ \\
\hline & 57 & 170 & 137 & 155 & 173 & $159 a$ \\
\hline Variety mean ${ }^{1}$ & & $173 a$ & $152 \mathrm{~b}$ & $173 a$ & $184 \mathrm{a}$ & \\
\hline $\begin{array}{l}\text { Variety mean (over } 3 \\
\text { dates) }^{1}\end{array}$ & & $179 a$ & $154 \mathrm{c}$ & $166 \mathrm{~b}$ & $171 \mathrm{~b}$ & \\
\hline
\end{tabular}

1 Variety means within each planting date, spacing mean within each planting date, and variety means over three planting dates, which have the same letter, do not differ at5-percentlevel of probability according to Duncan's Multiple Range Test.

TABLE 3.-Percent total rotenoids per unit of dry leaf weight for four varieties of TEPHROsm VOGEII when grown at three spacing distances and planted on three dates

\begin{tabular}{|c|c|c|c|c|c|c|c|}
\hline \multirow{2}{*}{ Planting dals } & \multirow{2}{*}{$\begin{array}{l}\text { Wilhin- } \\
\text { rawo } \\
\text { spacing }\end{array}$} & \multicolumn{5}{|c|}{ Percent total rotenoids/unit of dry leaf weight } & \multirow{2}{*}{$\begin{array}{l}\text { Spacing } \\
\text { meank }\end{array}$} \\
\hline & & 6286 & P.I. 257533 & P.I. 2482 & & P.I. 215495 & \\
\hline & $\mathrm{Cm}$. & & & & & & \\
\hline \multirow[t]{3}{*}{$4-1-64$} & 19 & 2.99 & 1.95 & 1.66 & & 2.21 & $2.20 \mathrm{a}$ \\
\hline & 34 & 2.84 & 1.95 & 1.70 & & 2.02 & $2.13 a$ \\
\hline & 57 & 2.81 & 1.82 & 1.32 & & 2.17 & $2.03 \mathrm{a}$ \\
\hline Variety mean' & & $2.88 \mathrm{a}$ & 1.90 & 1.56 & d & $2.13 \mathrm{~b}$ & \\
\hline \multirow{3}{*}{$4-29-64$} & 19 & 2.76 & 2.07 & 1.60 & & 2.17 & $2.15 a$ \\
\hline & 34 & 2.98 & 2.02 & 1.35 & & 1.97 & $2.08 \mathrm{a}$ \\
\hline & 57 & 3.06 & 1.84 & 1.48 & & 2.10 & $2.12 \mathrm{a}$ \\
\hline Variety mean ${ }^{1}$ & & $2.93 \mathrm{a}$ & $1.98 \mathrm{~b}$ & 1.41 & c & $2.08 \mathrm{~b}$ & \\
\hline \multirow[t]{3}{*}{$5-27-64$} & 19 & 2.77 & 1.99 & 1.75 & & 1.99 & $2.12 \mathrm{a}$ \\
\hline & 34 & 3.08 & 1.98 & 1.81 & & 2.17 & 2.258 \\
\hline & 57 & 2.93 & 1.91 & 1.83 & & 2.34 & $2.25 \mathrm{~g}$ \\
\hline Variety mean 1 & & $2.91 \mathrm{a}$ & $1.96 \mathrm{bc}$ & 1.80 & c & $2.17 \mathrm{~b}$ & \\
\hline $\begin{array}{l}\text { Variety mean (over } 3 \\
\text { dates) }^{1}\end{array}$ & & $2.91 a$ & $1.95 \mathrm{c}$ & 1.61 & $d$ & $2.13 \mathrm{~b}$ & \\
\hline
\end{tabular}

1 Variety means within each planting date, spacing mean within each planting date, and variety means over three planting dates, which have the same letter, do not differ at 5-percentlevel of probability according to Duncan's Multiple Range Test. 
TABLE 4.-Total dry weight (leaves and stems) per hectare of four varieties of

TEPHROSIA VOGELII when grown at three spacing distances and planted on three dates

\begin{tabular}{|c|c|c|c|c|c|c|}
\hline \multirow{2}{*}{ Planting date } & \multirow{2}{*}{$\begin{array}{l}\text { Wilhin- } \\
\text { roxp } \\
\text { spacing }\end{array}$} & \multicolumn{4}{|c|}{ Metric lons of tolal dry weight per hectare/variely } & \multirow{2}{*}{ Spacing mean ${ }^{1}$} \\
\hline & & 6286 & P.I. 257533 & P.I. 248228 & P.I. 215495 & \\
\hline & $C m$. & & & & & \\
\hline \multirow[t]{3}{*}{$4-1-64$} & 19 & 12.6 & 13.3 & 12.4 & 12.0 & $12.6 \mathrm{a}$ \\
\hline & 34 & 12.2 & 11.0 & 10.4 & 9.6 & $10.8 \mathrm{ab}$ \\
\hline & 57 & 7.8 & 8.3 & 8.0 & 4.4 & $7.1 \mathrm{~b}$ \\
\hline Variety mean 1 & & $10.9 \mathrm{a}$ & $10.9 \mathrm{a}$ & $10.3 \mathrm{a}$ & $8.6 \mathrm{a}$ & \\
\hline \multirow[t]{3}{*}{ 4-29-64 } & 19 & 11.3 & 13.4 & 17.1 & 12.0 & $13.5 \mathrm{a}$ \\
\hline & 34 & 9.8 & 11.7 & 8.4 & 7.3 & $9.3 \mathrm{~b}$ \\
\hline & 57 & 8.9 & 5.7 & 4.3 & 3.5 & $5.6 \mathrm{~b}$ \\
\hline Variety mean 1 & & $10.0 \mathrm{a}$ & $10.3 a$ & $9.9 \mathrm{a}$ & $7.6 \mathrm{a}$ & \\
\hline \multirow[t]{3}{*}{$5-27-64$} & 19 & 17.1 & 13.7 & 19.3 & 15.5 & $16.4 a$ \\
\hline & 34 & 10.0 & 9.3 & 10.4 & 10.1 & $10.0 \mathrm{~b}$ \\
\hline & 57 & 8.4 & 7.7 & 7.3 & 9.9 & $8.3 \mathrm{~b}$ \\
\hline Variety mean ${ }^{1}$ & & $11.8 \mathrm{a}$ & $10.2 \mathrm{a}$ & $12.3 \mathrm{a}$ & $11.8 \mathrm{a}$ & \\
\hline $\begin{array}{l}\text { Variety mean (over } 3 \\
\text { dates) }^{1}\end{array}$ & & $10.9 \mathrm{a}$ & 10.58 & $10.8 \mathrm{a}$ & 9.48 & \\
\hline
\end{tabular}

1 Variety means within each planting date, spacing mean within each planting date, and variety means over three planting dates, which have the same letter, do not differ at 5-percent level of probability according to Duncan's Multiple Range Test.

TABLE 5.-Leaf-to-stem ratio of four varieties of TEPHROsIA VOGELI when grown at three spacing distances and planted on three dates

\begin{tabular}{|c|c|c|c|c|c|c|}
\hline Planting Date & $\begin{array}{l}\text { Wilhin- } \\
\text { rown } \\
\text { spacing }\end{array}$ & 6286 & $P . I .257533$ & P.I. 248228 & P.I. 215495 & $\begin{array}{c}\text { Spacing } \\
\text { mean }^{1}\end{array}$ \\
\hline & (cm.) & & & & & \\
\hline \multirow[t]{3}{*}{$4-1-64$} & 19 & .23 & .30 & .38 & .22 & $.28 \mathrm{a}$ \\
\hline & 34 & .26 & .36 & .34 & .32 & $.32 a$ \\
\hline & 57 & .32 & .34 & .34 & .39 & $.35 a$ \\
\hline Variety mean 1 & & $.27 \mathrm{~b}$ & $.33 \mathrm{a}$ & $.35 a$ & $.31 a b$ & \\
\hline \multirow[t]{3}{*}{ 4-29-64 } & 19 & .34 & .42 & .37 & .42 & $.39 \mathrm{~b}$ \\
\hline & 34 & .42 & .48 & .58 & .58 & $.51 a b$ \\
\hline & 57 & .52 & .53 & .67 & .56 & $.57 a$ \\
\hline Variety mean ${ }^{1}$ & & $.43 \mathrm{~b}$ & $.48 \mathrm{ab}$ & $.39 a$ & $.39 a$ & \\
\hline \multirow{3}{*}{$5-27-64$} & 19 & .40 & .48 & .39 & .39 & $.41 \mathrm{a}$ \\
\hline & 34 & .45 & .54 & .46 & .43 & $.47 \mathrm{a}$ \\
\hline & 57 & .46 & .60 & .53 & .44 & $.51 \mathrm{a}$ \\
\hline Variety mean ${ }^{1}$ & & $.44 \mathrm{~b}$ & $.54 \mathrm{a}$ & $.46 \mathrm{~b}$ & $.42 \mathrm{~b}$ & \\
\hline $\begin{array}{l}\text { Variety mean (over } 3 \\
\text { dates) } 1\end{array}$ & & $.37 \mathrm{c}$ & $.45 a$ & $.45 \mathrm{a}$ & $.41 \mathrm{~b}$ & \\
\hline
\end{tabular}

1 Variety means within each planting date, spacing mean within each planting date, and variety means over three planting dates, which have the same letter, do not differ at 5-percent level of probability according to Duncan's Multiple Range Test. 
stem ratio over all planting dates and varieties was $.36, .44$, and .47 for the 19-, 34-, and 57-cm. within-row spacings, respectively.

Total rotenoid production per hectare was calculated for each of the treatments and varieties (table 6). These calculations were based on the percent total rotenoids per unit of dry leaf weight, total dry weight harvested per hectare and leaf-to-stem ratios. The rotenoid content of the stem portion of the plant was estimated on the basis of unpublished data (Fed. Exp. Sta., Mayagüez, P.R.) which indicated that stems contain

TABLE 6.-Total rotenoid produced per hectare by four varielies of TEPHROsIA voGruI when grown at three spacing distances and planted on three dates

\begin{tabular}{|c|c|c|c|c|c|c|c|c|}
\hline \multirow{2}{*}{ Planting dale } & \multirow{2}{*}{$\begin{array}{l}\text { Within- } \\
\text { rowo } \\
\text { spocing }\end{array}$} & \multicolumn{6}{|c|}{ Kilograms tolal rolenoids/hectare/oariely } & \multirow{2}{*}{ Spacirs mean } \\
\hline & & 6286 & P.I. 257533 & P.I. 248 & 8228 & P.I.215 & & \\
\hline & $\mathrm{Cm}$. & & & & & & & \\
\hline \multirow{3}{*}{$4-1-64$} & 19 & 183 & 139 & 122 & & 124 & & $142 a$ \\
\hline & 34 & 171 & 144 & 99 & & 105 & & $129 \mathrm{~b}$ \\
\hline & 57 & 120 & 105 & 59 & & 57 & & $85 \mathrm{c}$ \\
\hline Variety mean ${ }^{1}$ & & $158 \mathrm{a}$ & $129 \mathrm{~b}$ & 93 & c & 95 & c & \\
\hline \multirow{3}{*}{$4-29-64$} & 19 & 177 & 169 & 163 & & 161 & & $168 \mathrm{a}$ \\
\hline & 34 & 180 & 155 & 81 & & 106 & & $131 \mathrm{~b}$ \\
\hline & 57 & 184 & 73 & 49 & & 51 & & $89 \mathrm{c}$ \\
\hline Variety mean 1 & & $180 \mathrm{a}$ & $132 b$ & 98 & c & 106 & c & \\
\hline \multirow[t]{3}{*}{$5-27-64$} & 19 & 287 & 178 & 200 & & 186 & & $213 a$ \\
\hline & 34 & 189 & 126 & 129 & & 133 & & $144 \mathrm{~b}$ \\
\hline & 57 & 157 & 108 & 99 & & 145 & & $127 \mathrm{~b}$ \\
\hline Variety mean ${ }^{1}$ & & $211 \mathrm{a}$ & $137 \mathrm{~b}$ & $143 \mathrm{~b}$ & & $155 \mathrm{~b}$ & b & \\
\hline $\begin{array}{l}\text { Variety mean (over } 3 \\
\text { dates) }^{1}\end{array}$ & & $183 a$ & $133 \mathrm{~b}$ & 111 & c & 119 & c & \\
\hline
\end{tabular}

1 Variety means within each planting date, spacing mean within each planting date, and variety means over three planting dates, which have the same letter, do not differ at5-percent level of probability according to Duncan's Multiple Range Test.

about one-third the percentage of total rotenoids that is present in leaves. The most productive treatment for all varieties was the $19-\mathrm{cm}$. within-row spacing planted on May 27.

Seed production per plant varied significantly among varieties (table 7). Differences in seed yield per plant due to planting date and within-row spacings were not statistically significant, but seed yield/plant tended to be greatest on plant spacings of $57 \mathrm{~cm}$. However, when these data were converted to total seed production per hectare the mean yield over all dates and varieties was approximately 550,320 , and $300 \mathrm{~kg}$. for the 19 -, $34-$, and $57-\mathrm{cm}$. within-row spacings, respectively. Although the $57-\mathrm{cm}$. within-row spacing yielded the highest number of seeds per plant, the seed 
production per hectare was the lowest at such distance due to the difference in plant population density.

\section{DISCUSSION}

The primary goal of all crop management systems is to obtain greatest return at lowest cost. Data obtained from the present study indicate that time of planting, within-row spacing and variety are all important con-

TABLE 7.-Seed yield per plant of four varieties of TEPHROsIA vOGEUI when grown at three spacing distances and planted on three dates

\begin{tabular}{|c|c|c|c|c|c|c|}
\hline \multirow{2}{*}{ Planting date } & \multirow{2}{*}{$\begin{array}{l}\text { Within- } \\
\text { sown } \\
\text { spocing }\end{array}$} & \multicolumn{4}{|c|}{ Seed/plant (grams/variety) } & \multirow{2}{*}{$\underset{\text { means }}{\text { Spacing }}$} \\
\hline & & 6286 & P.I. 257533 & P.I. 248228 & P.I. 215495 & \\
\hline & $\mathrm{Cm}$. & & & & & \\
\hline \multirow[t]{3}{*}{$4-1-64$} & 19 & 4.4 & 3.8 & 9.3 & 2.8 & $5.1 \mathrm{a}$ \\
\hline & 34 & 3.0 & 10.1 & 17.3 & 0.9 & $7.8 \mathrm{a}$ \\
\hline & 57 & 11.9 & 13.5 & 39.8 & 6.3 & $17.9 \mathrm{a}$ \\
\hline Variety mean ${ }^{1}$ & & $6.4 \mathrm{~b}$ & $9.1 \mathrm{~b}$ & $22.1 \mathrm{a}$ & $3.3 \mathrm{~b}$ & \\
\hline \multirow[t]{3}{*}{$4-29-64$} & 19 & 5.8 & 10.4 & 22.0 & 3.1 & $10.3 a$ \\
\hline & 34 & 11.8 & 22.4 & 7.3 & 3.1 & $11.1 \mathrm{a}$ \\
\hline & 57 & 27.3 & 16.2 & 18.2 & 3.9 & $16.4 \mathrm{a}$ \\
\hline Variety mean ${ }^{1}$ & & $15.0 \mathrm{a}$ & $16.3 \mathrm{a}$ & $15.8 \mathrm{a}$ & $3.4 \mathrm{a}$ & \\
\hline \multirow[t]{3}{*}{$5-27-64$} & 19 & 7.2 & 28.3 & 13.2 & 3.2 & $13.0 \mathrm{a}$ \\
\hline & 34 & 4.6 & 16.4 & 18.6 & 3.2 & $10.7 \mathrm{a}$ \\
\hline & $\mathbf{5 7}$ & 9.7 & 11.3 & 20.6 & 7.6 & $12.3 \mathrm{a}$ \\
\hline Variety mean 1 & & $7.1 \mathrm{a}$ & $18.7 \mathrm{a}$ & $17.5 \mathrm{a}$ & $4.7 \mathrm{a}$ & \\
\hline $\begin{array}{l}\text { Variety mean (over } \\
3 \text { dates) }\end{array}$ & & $9.5 \mathrm{bc}$ & $14.7 \mathrm{ab}$ & $18.5 \mathrm{a}$ & $3.8 \mathrm{c}$ & \\
\hline
\end{tabular}

1 Variety means within each planting date, spacing mean within each planting date, and variety means over three planting dates, which have the same letter, do not differ at 5-percent level of probability according to Duncan's Multiple Range Test.

siderations in a crop management system for growing Tephrosia vogelii for rotenoid production in Puerto Rico.

The highest rotenoid production per hectare was obtained from the May 27 planting. Earlier plantings tended to produce taller plants, but neither the percentage of total rotenoids per unit of dry leaf weight nor the total leaf and stem production was increased. The early plantings also had a lower proportion of leaves to stems than the late May planting. When all of these factors were considered, plus the cost of maintaining the crop for an extra 6 weeks as in the case of line 6286, it does not appear practical to plant Tephrosia earlier than late May.

The Tephrosia plant will compensate to some degree the variations in plant spacing. Plants spaced $57 \mathrm{~cm}$. within the row produced much more axillary branching than plants spaced $19 \mathrm{~cm}$. Nevertheless, the greatest 
hectare production of total rotenoids was obtained from closely-spaced plant populations of about 53,000 plants per hectare. It was reported earlier by Barnes et al. (3) that plant populations of 30,000 to 37,000 plants per hectare were the most adequate planting density. However, this was for a late April planting. Additional plant population and hill vs. row-planting trials should be conducted to determine if more productive planting designs can be demonstrated.

Seed production costs are a very important consideration in the economics of Tephrosia production. At present all seed must be produced in tropical or semi-tropical areas because of the photoperiodic requirements of the crop. The best seed production per hectare in previous studies conducted in Puerto Rico (2) has been about 450 to $500 \mathrm{~kg} / \mathrm{ha}$. The highest yields in the present study (about $550 \mathrm{~kg}$./ha.) were obtained from the $19-\mathrm{cm}$. withinrow spacing. The significant differences in seed production among varieties indicate possibilities of breeding higher seed-producing characteristics into our new experimental lines.

The present indications are that commercial rotenoid extraction can best be done by extracting the rotenoids from freshly harvested plants. Both the stems and leaves would be harvested with a silage harvester. The best yields achieved in this study approach the level needed for profitable production in Puerto Rico. When considering the feasibility of commercial Tephrosia production in Puerto Rico, it should be pointed out that it will allow land to be double cropped with Tephrosia grown from late May to mid-November and a crop like sorghum grown from November to April. The data obtained from this study demonstrate that yields of total rotenoids as high as $280 \mathrm{~kg}$. can now be obtained from high-producing varieties planted in late May, at populations of about 53,000 plants/ha. New breeding lines with higher levels of rotenoids are being tested at the Federal Experiment Station. These new lines should increase the potential rotenoid production of Tephrosia in Puerto Rico by 25 to 40 percent.

\section{SUMMARY}

The effect of within-row plant spacing (approximately 19, 34 and $57 \mathrm{~cm}$.) and time of planting (April 1, April 29, May 27) on rotenoid and seed production of Tephrosia vogelii in Puerto Rico is reported. Percent total rotenoids and seed yield per plant varied among lines, but were not significantly affected by plant spacing and time of planting. Planting date significantly affected time from planting to flowering and proportion of leaves to stem. The April 1 planting date increased number of days to flowering, thereby increasing leaf losses from diseases and senescence as compared to the April 29 and May 27 planting dates. Plant spacing significantly affected plant height, total plant dry weight per hectare and proportion of leaves to stem. Close plant-spacing tended to increase plant 
height and total dry plant weight, and to lower proportion of leaves. These results indicated that the most efficient crop management system of $T$. vogelii for Puerto Rico would include a May 27 planting date, with a plant population of about 53,000 plants per hectare. Experimental yields of approximately $280 \mathrm{~kg}$. of total rotenoids or $550 \mathrm{~kg}$. of seed per hectare were obtained from this management system.

\section{RESUMEN}

Este artículo informa sobre el efecto de tres diversas distancias de siembra entre plantas (19, 34 y $57 \mathrm{~cm}$. aproximadamente) y tres fechas de siembra (abril 1, abril 29 y mayo 27) en la producción de semilla y contenido de rotenoides en Tephrosia vogelii. Aunque los dos criterios bajo consideración variaron entre las líneas que se usaron en el experimento, éstos no fueron afectados por las distancias ni por las fechas de siembra. Las fechas influyeron significativamente en cuanto al tiempo requerido para la florecida, aś como en la proporción de hojas a tallos. Las plantas que se sembraron en abril 1 requirieron más días para florecer, al compararse con las que se sembraron en abril 29 y mayo 27 , y por consecuencia, la pérdida de hojas fue mayor en las primeras a causa de las enfermedades y a su envejecimiento. Las distancias de siembra afectaron significativamente la altura de las plantas, la producción de materia seca total por hectárea y la proporción de hojas a tallos. Las distancias más cortas tendieron a producir plantas más altas, mayor cantidad de tallos y hojas secas, y una disminución en la proporción de hojas a tallos. Los resultados indican que para obtener el mejor provecho de $T$. vogelii en Puerto Rico, las siembras deben hacerse en mayo 27 y a una densidad de 53,000 plantas por hectárea. Mediante este sistema de siembra se obtuvieron experimentalmente alrededor de $280 \mathrm{~kg}$. de rotenoides totales, o sea $550 \mathrm{~kg}$. de semilla por hectárea.

\section{LITERATURE CITED}

1. Barnes, D. K., and Freyre, R. H., Recovery of natural insecticides from Tephrosia vogelii. III. An improved procedure for sampling and assaying rotenoid content in leaves, Econ. Bot. $81:$ :3-8, 1967.

2. Barnes, D. K., and Freyre, R. H., Seed production potential of Tephrosia vogelii in Puerto Rico, J. Agr. Univ. P.R. 58(3): 207-12, 1969.

3. Barnes, D. K., Freyre, R. H., Higgins, J. J., and Martin, J. A., Rotenoid content and growth characteristics of Tephrosia vogelii as affected by latitude and within-row spacings, Crop Sci. 7: 93-5, 1967.

4. Duncan, D. B., Multiple range and multiple F tests, Biometrics 11: 1-42, 1955.

5. Irvine, J. E., and Freyre, R. H., Occurrence of rotenoids in some species of the genus Tephrosia, Agr. \& Food Chem. 7: 106-7, 1959.

6. Irvine, J. E., and Freyre, R. H., Varietal differences in the rotenoid content of Tephrosia vogelii, Agron. J. 51: 664-65, 1959.

7. Ruppel, E. G., Barnes, D. K., Freyre, R. H., and Santiago, Alma, Effect of seed protectant and planting depth on Pythium and Rhizoctonia damping-off of Tephrosia vogelii in Puerto Rico, Plant Dis. Reptr. 48: 714-17, 1964. 